\title{
Effect of Antimicrobials on Salmonella Spp. Strains Isolated from Poultry Processing Plants
}

\section{-Author(s)}

\author{
Mion L' \\ Parizotto $\mathrm{L}^{\prime}$ \\ Calasans $\mathrm{M}$ \\ Dickel EL' \\ Pilotto $F^{\prime}$ \\ Rodrigues LB \\ Nascimento VP \\ Santos LR'
}

Curso de Medicina Veterinária -

Universidade de Passo Fundo

\begin{abstract}
The routine use of antimicrobials in animal production for the treatment of infections, disease prevention, or as growth promoters is a predisposing factor for the development and dissemination of antimicrobial resistance. In food industries, sanitizers are used for the control of microbial colonization, and their efficacy depends on contact time and on the dilution of the products used. The present study assessed the effect of 12 antimicrobials and four commercial sanitizers on 18 Salmonella spp. strains isolated from poultry processing plants. None of the evaluated antimicrobials was 100\% effective against the tested Salmonella spp. strains; however, $94 \%$ of the isolates were susceptible to ciprofloxacin, $77 \%$ to amoxicillin + clavulanic acid and to ampicillin, and $72 \%$ to enrofloxacin, whereas $100 \%$ of the isolates were resistant to penicillin G, $16 \%$ to tetracycline, and $11 \%$ to sulfonamide. The tested Salmonella spp. strains were $100 \%$ inhibited by peracetic acid after five minutes of contact, $0.5 \%$ by quaternary ammonium after 15 minutes, and $85.7 \%$ by chlorhexidine after 15 minutes. The results indicate the importance of testing of efficacy of antimicrobials used in animal production and in public health to monitor their action and the development of resistance.
\end{abstract}

\section{INTRODUCTION}

The routine use of antimicrobials in animal production for the treatment of infections, disease prevention, and as growth promoters, may lead to the development and dissemination of antimicrobial resistance, which is later transmitted to human beings in the food chain (EFSA, 2014).

The sanitation standard operating procedures (SSOP) applied in processing plants aim at controlling the dissemination of microorganisms and the formation of biofilm on the surfaces with which the food has contact; however, bacteria of the genus Salmonella are known for their adhesion to surfaces and resistance to sanitizers (Rodrigues et al., 2013). The most commonly products used in SSOP in poultry processing plants are peracetic acid, quaternary ammonium, and chlorhexidine. The selection and use of sanitizers are crucial for the reduction of microbial counts. However, the degree of hygiene and type of surfaces of processing plants bacterial growth (Baltreme, 2014), and should be known when testing the efficacy of sanitizers applied in such facilities.

This study evaluated the efficacy of 12 antimicrobials and four commercial sanitizers on $18 \mathrm{Salmonella} \mathrm{spp.} \mathrm{strains} \mathrm{isolated} \mathrm{from}$ poultry processing plants.

\section{MATERIALS AND METHODS}

Salmonella spp. strains were isolated from seven broiler processing plants under federal inspection services in the state of Rio Grande do 
Mion L, Parizotto L, Calasans M, Dickel EL, Pilotto F, Rodrigues LB, Nascimento VP, Santos LR
Effect of Antimicrobials on Salmonella Spp. Strains Isolated from Poultry Processing Plants
Sul, Brazil, between 2012 and 2014. A total of 1,071 samples were collected, out of which $18(1.68 \%)$ were positive for Salmonella spp. The samples positive for Salmonella spp were determined in cloacal swabs $(n=6)$, transport crate swabs after washing $(n=3)$, carcasses after plucking $(n=1)$, carcasses after the first wash $(n=1)$, plucked and washed carcasses $(n=1)$, eviscerated carcasses $(n=1)$, at the exit of the chiller $(n=1)$, after final wash $(n=1)$, carcasses chilled at $4^{\circ} \mathrm{C}$ $(n=1)$, carcasses frozen at $-12^{\circ}$ for 24 hours $(n=1)$, and carcasses frozen at $-12^{\circ} \mathrm{C}$ for 60 days $(n=1)$. The samples were processed at the Laboratory of Bacteriology and Mycology of the Veterinary Hospital of the University of Passo Fundo (HV-UPF), Brazil, using Salmonella Enteritidis ATCC 13076 as positive control.

Cloacal swabs were taken from 300 broilers in each collection, using one swab for every two birds, making up a pool of 50 swabs that were stored in flasks containing $50 \mathrm{~mL}$ of buffered peptone water (BPW 1.0\%, HiMedia ${ }^{\circledR}$ ). In the laboratory, pools were homogenized and 10-mL aliquots were used for Salmonella spp isolation.

Transport crates were sealed with official labels and sampled by rubbing $3 \mathrm{M}^{\circledR}$ sponge sticks with neutralizing buffer across the inner side of the crate before and after washing and disinfection. The sponges were placed the collection bags provided by the manufacturer and $50 \mathrm{~mL}$ of $1.0 \%$ BPW was added; a 10-mL aliquot was used for Salmonella spp isolation.

Birds and carcasses were placed in individual plastic bags sealed with official labels and rinsed with 400 $\mathrm{mL}$ of $1.0 \%$ BPW, and a $10-\mathrm{mL}$ aliquot was used for analyses.

For the isolation of Salmonella spp., $10-\mathrm{mL}$ aliquots of $1.0 \%$ BPW were incubated at $37 \pm 1^{\circ} \mathrm{C}$ for 16 to 20 hours. Subsequently, $1 \mathrm{~mL}$ was inoculated in 9 $\mathrm{mL}$ tetrathionate broth $\left(\operatorname{Merck}^{\circledR}\right)$ and incubated at $37 \pm 1^{\circ} \mathrm{C}$ for $24 \pm 3$ hours, and $100 \mu \mathrm{L}$ were inoculated in $9.9 \mathrm{~mL}$ Rappaport-Vassiliadis broth $\left(\right.$ Merck $^{\circledR}$ ) and incubated at $41.5 \pm 1^{\circ} \mathrm{C}$ for $24 \pm 3$ hours. The samples were then streaked onto Rambach Agar $\left(\right.$ Merck $^{\circledR}$ ) and Brilliant Green Agar supplemented with Novobiocin (Merck ${ }^{\circledR}$ ), and incubated at $37 \pm 1^{\circ} \mathrm{C}$ for $24 \pm 3$ hours. Suspected Salmonella spp. colonies were transferred to Triple Sugar Iron (TSI) agar (Merck $\left.{ }^{\circledR}\right)$, Lysine Iron Agar (Merck ${ }^{\circledR}$ ), Sulfite Indole Motility (SIM) medium $\left(\operatorname{Merck}^{\circledR}\right)$, Urea Broth $\left(\operatorname{Merck}^{\circledR}\right)$, and then confirmed by Poly O Antiserum (Probac ${ }^{\circledR}$ ).

For the antimicrobial sensitivity tests (CLSI, 2012), Salmonella spp isolates were incubated in $\mathrm{BHI}$ broth (HiMedia ${ }^{\circledR}$ ) at $36 \pm 1{ }^{\circ} \mathrm{C}$ for 16 to 18 hours. A suspension equivalent to a 0.5 McFarland standard was obtained by dilution in $\mathrm{BHI}$ broth and used for the inoculation of tested bacteria onto Mueller-Hinton agar $\left(\mathrm{Oxoid}^{\circledR}\right)$ plates. The assessed antimicrobials $\left(\right.$ Laborclin $^{\circledR}$ ) were selected because are regularly used to treat human salmonellosis and farm animals, either as therapeutic agents or as growth promoters, and included amoxicillin + clavulanic acid (30 $\mu \mathrm{g})$, ampicillin $(10 \mu \mathrm{g})$, ceftiofur $(30 \mu \mathrm{g})$, chloramphenicol $(30 \mu \mathrm{g})$, enrofloxacin $(5 \mu \mathrm{g})$, streptomycin $(10 \mu \mathrm{g})$, gentamicin $(10 \mu \mathrm{g})$, neomycin $(30 \mu \mathrm{g})$, benzyl penicillin $(10 \mathrm{u})$, sulfonamide $(300 \mu \mathrm{g})$, ciprofloxacin $(5 \mu \mathrm{g})$, and tetracycline $(30 \mu \mathrm{g})$. After incubation at $36 \pm 1^{\circ} \mathrm{C}$ for 16 to 18 hours, results were interpreted according to a specific table (Laborclin ${ }^{\circledR}$ ) and as recommended by Clinical and Laboratory Standards Institute (USDA, 2012). Multiresistance was determined according to he National Antimicrobial Resistance Monitoring System criteria (USDA, 2012) were applied, according to which multiresistance is the resistance to three or more classes of antimicrobials.

For testing the efficacy of sanitizers, according to Beltrame (2009), sanitizers were tested at the dilutions routinely used in processing plants, as follows: $0.5 \%$ chlorhexidine, $0.5 \%$ and $1 \%$ quaternary ammonium, and $1 \%$ peracetic acid, were utilized. The bacteria previous stored at $-20^{\circ} \mathrm{C}$ in $\mathrm{BHI}$ broth with $20 \%$ glycerin were inoculated in $\mathrm{BHI}$ broth $\left(\mathrm{HiMedia}^{\circledR}\right.$ ) and incubated at $37^{\circ} \mathrm{C}$ for 18 hours. Subsequently, $100 \mu \mathrm{L}$ of the Salmonella spp. culture were added to sterile tubes containing $9 \mathrm{~mL}$ of the sanitizer at the tested concentration and $1 \mathrm{~mL}$ of UHT whole milk (to simulate the presence of organic matter). After contact times of $1,5,10$ and $15 \mathrm{~min}, 10-\mu \mathrm{L}$ aliquots were transferred to $5.0 \mathrm{~mL}$ of BHI broth and incubated for 96 hours at $37^{\circ} \mathrm{C}$. The bacteria were considered resistant $(R)$ when the culture medium presented turbidity, film formation on the surface, or precipitation, and susceptible (S) in the absence of turbidity. In this case, positive samples were seeded onto brilliant green agar plates to check bacterial viability.

\section{RESULTS AND DISCUSSION}

None of the tested antimicrobials was 100\% effective against the isolated Salmonella spp. (Figure 1).

Chloramphenicol is used to treat human salmonellosis, due to its low cost and adequate therapeutic response (Alecrim et al., 2002). Colla et al. (2012) reported $25.6 \%$ resistance and $64.1 \%$ of intermediate resistance to this drug in Salmonella Typhimurium and Panama serovars, respectively, 


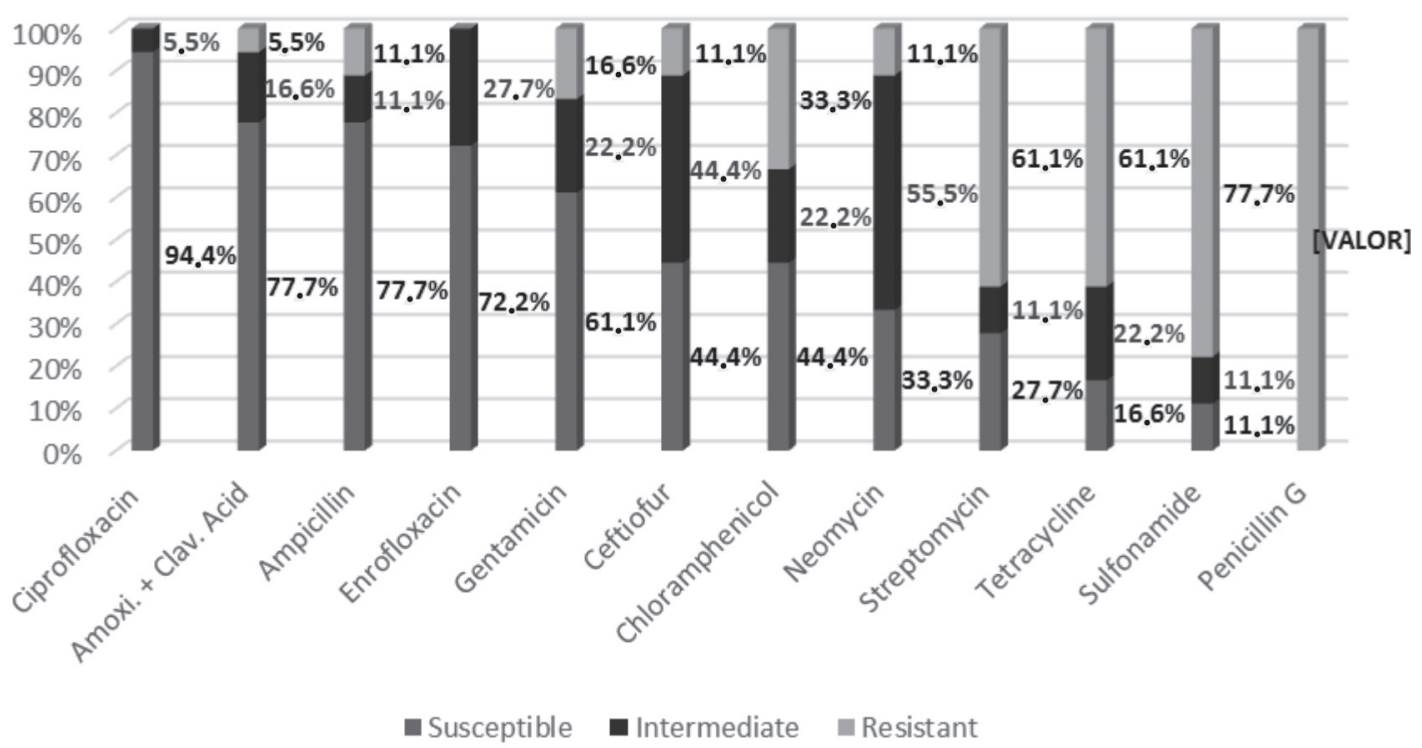

Figure 1 -Antimicrobial sensitivity of 18 Salmonella spp. samples isolated from poultry processing plants.

isolated from swine carcasses, while Mion et al. (2014) observed 100\% efficacy of chloramphenicol, enrofloxacin, ciprofloxacin, and streptomycin against Salmonella Heidelberg isolated from poultry processing plants between 2005 and 2009. However, in the present study, only ciprofloxacin was more than $90 \%$ effective against Salmonella spp isolated between 2012 and 2014, suggesting a possible development of resistance of this bacterium during this period.

Tetracyclines are one of the most widely classes of antimicrobials therapeutically in livestock (Wilson, 2004). In the present study, $61.1 \%$ of the isolates were resistant to this drug, indicating that its continuous use has increased microbial resistance, consequently reducing the available therapeutic options. Tetracyclines and aminoglycosides (gentamicin and streptomycin), amoxicillin with clavulanic acid, ampicillin, and ciprofloxacin are considered by the World Health Organization to be critically important for human medicine (WHO, 2011). The resistance of bacteria to such drugs has increased (EFSA, 2014), and represent a substantial cost to public health as resistant bacteria are more harmful to patients than susceptible strains of the same species (Balsalobre et al., 2014). Therefore, increasing rates of multi-resistant bacteria represent a potential public health hazard (Chiappini et al. 2002, Zimermann 2008).

In a survey carried out in 2010 in the European Union, Salmonella spp. isolated from poultry meat and showed $27 \%, 24 \%, 24 \%, 21 \%, 20 \%, 4 \%, 3 \%$ and $2 \%$ resistance to sulfonamide, ciprofloxacin, nalidixic acid, ampicillin, tetracycline, cefotaxime, chloramphenicol, and gentamicin respectively, which are similar to the rates detected in Salmonella strains isolated from humans. In the European Community, fluoroquinolones are used as first-line treatment against salmonellosis in adults, while third-generation cephalosporins are used in children, yielding resistant strains due to misuse and resulting in inefficient therapy, also causing multiresistance (EFSA 2014).

Drug multiresistance is described by the National Antimicrobial Resistance Monitoring System (USDA, 2012) as resistance to three or more classes of antimicrobials, and the ACSSUT R-type stands for the resistance to ampicillin (A), chloramphenicol (C), streptomycin (S), sulfonamide (Su), and tetracycline (T) (Reis et al., 2011). In the present study, a Salmonella spp. isolate from a cloacal swab presented intermediate resistance to ampicillin and resistance to ceftiofur, chloramphenicol, streptomycin, gentamicin, neomycin, penicillin g, sulfonamide, and tetracycline, suggesting that broiler flocks on the farm may host ACSSUT multiresistant Salmonella strains (Figure 2).

Considering the possible transfer of such resistance to the human population, the European Union banned the use of antibiotics as growth promoters in animal production as of January 2006. Because Brazil is one of the main poultry exporters to the EU, Brazilian companies needed to comply with EU legislation (Lorenço et al., 2007). In July 2009, the Brazilian Ministry of Agriculture (Brasil, 2012) banned the use of amphenicols, tetracycline, beta-lactams (benzylpenicillins and cephalosporins), quinolones, and sulfonamides as performance enhancers or 
Mion L, Parizotto L, Calasans M, Dickel EL, Pilotto F, Rodrigues LB, Nascimento VP, Santos LR

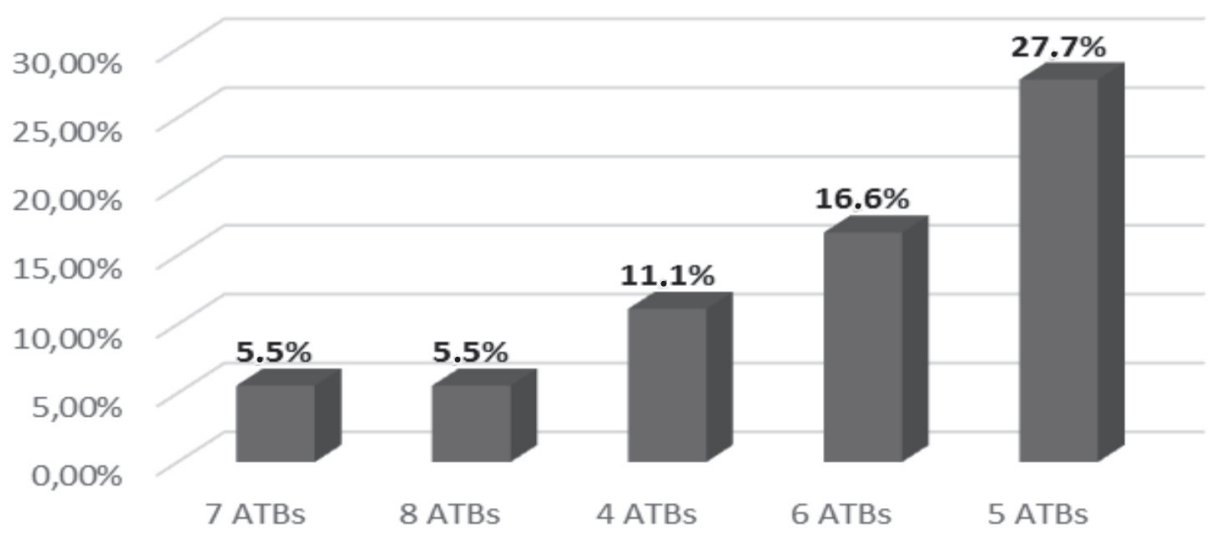

Figure 2 - Multiresistance of 18 Salmonella spp. samples isolated from poultry processing plants according to the number of antibiotics (ATBs)

as food preservers, limiting their use to veterinary treatments. Finally, in May 2012, the use of spiramycin and erythromycin as performance enhancers in animal production was also banned (Brasil, 2012).

The in-vitro assessment of the effect of commercial sanitizers against Salmonella spp. strains showed that only peracetic acid was $100 \%$ effective after 5 min of contact (Figure 3). Peracetic acid quickly acts against bacteria and it is more effective against biofilm formation because of its higher inhibitory potential of bacteria and in a shorter time of exposure compared with other sanitizers (Rodrigues et al., 2013). The stronger inhibitory effect of $1 \%$ quaternary ammonium $(42.9 \%$ to $100 \%)$ compared with $0.5 \%$ (57.2\% to $85.7 \%$ ), as shown in Figure 3, emphasizes the need to test the efficacy of disinfectants sold by different manufacturers, as commercial formulations may present different dilutions of the active ingredients. The weak effect of chlorhexidine may be due to its continuous use in dental, medical, and veterinary treatments since the 1950s, producing resistance because of its prolonged use and its inappropriate contact time and dilutions (Colla et al., 2014). These results highlight that the effect of sanitizers against Salmonella strains is associated with practical situations, particularly with the presence of organic matter, contact time, and with the resistance developed by bacteria to the most common disinfectants.

\section{ACKNOWLEDGMENTS}

We thank the Research Incentive Foundation of the State of Rio Grande do Sul (FAPERGS - Process 12/2312-4) for the financial support.

\section{REFERENCES}

Alecrim WD, Loureiro ACSP, Moraes RS, Monte RL, Lacerda MVG. Febre tifóide: recaída por resistência antimicrobiana. Relato de caso. Revista da Sociedade Brasileira de Medicina Tropical 2002;35:661-663.

Balsalobre LC, Dropa M, Matté MH. An overview of antimicrobial resistance and its public health significance. Brazilian Journal of Microbiology 2014; $45: 1-5$.

Beltrame CA. Avaliação da eficiência de sanitizantes utilizados pelas indústrias de alimentos. Erechim: Universidade Regional Integrada do Alto Uruguai e das Missões; 2009.

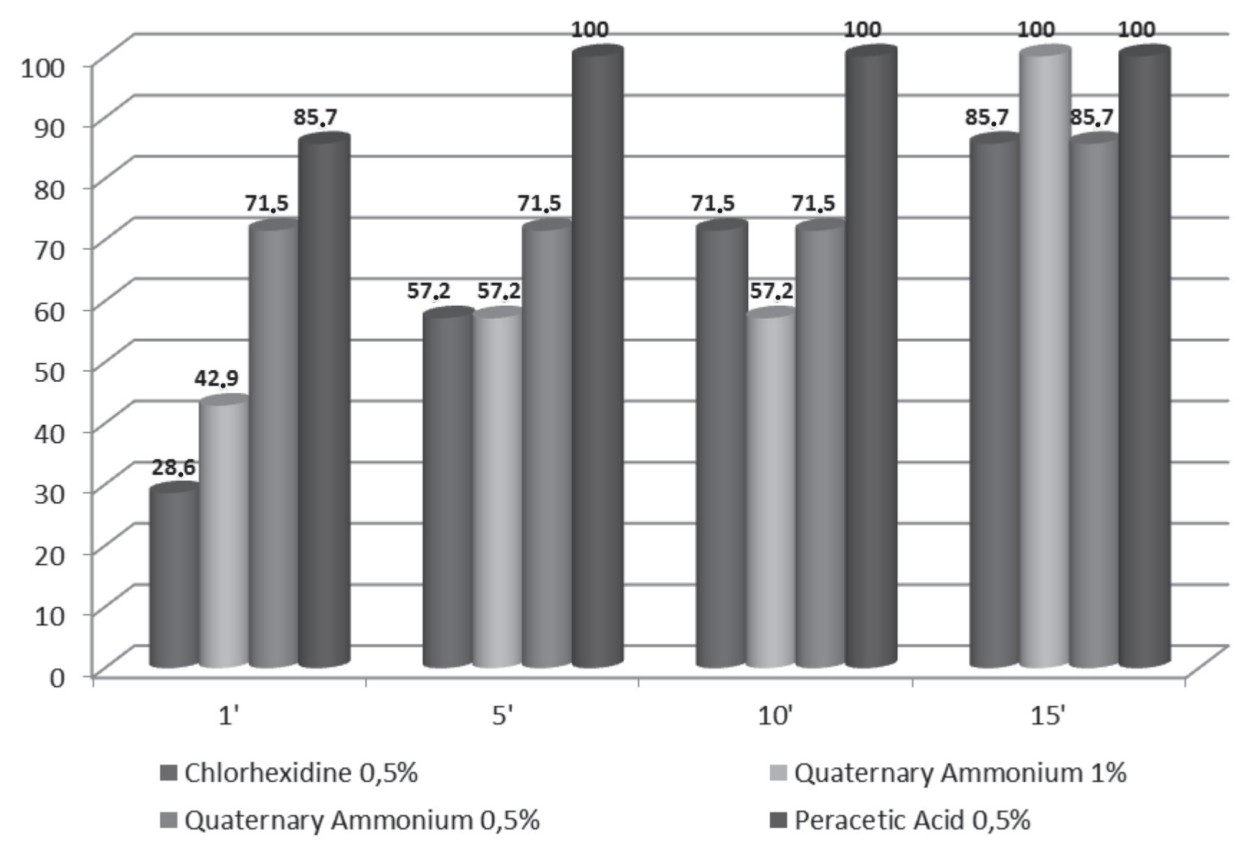

Figure 3 - Effect of commercial sanitizers and different contact times against 18 Salmonella spp. samples isolated in poultry processing plants. 
Mion L, Parizotto L, Calasans M, Dickel EL, Pilotto F, Rodrigues LB, Nascimento VP, Santos LR
Effect of Antimicrobials on Salmonella Spp. Strains Isolated from Poultry Processing Plants
Beltrame CA. Avaliação da adesão e remoção de biofilmes de Listeria monocytogenes e Escherichia coli em diferentes superfícies e indução de resistência bacteriana, com diferentes sanitizantes [tese]. Erechim (RS): Universidade Regional Integrada do Alto Uruguai e das Missões; 2011.

Brasil. Ministério da Agricultura, Pecuária e Abastecimento. Instrução Normativa $n^{\circ} 14$, de 18 de maio de 2012. Proibi em todo o território nacional a importação, fabricação e o uso das substâncias antimicrobianas espiramicina e eritromicina com finalidade de aditivo zootécnico melhorador de desempenho na alimentação animal [cited 2012 maio 28]. Available from: http://www.agricultura. gov.br/arq_editor/file/CRC/IN\%20142012\%20\%20proibe\%20 antimicrobianos $\% 20$ espiramicina $\% 20 \% 20$ e $\% 20$ eritromicina $\% 20$ melh\%20desemp.pdf

Chiappini E, Galli L, Pecile P, Vierucci A, Martino M. Results of a 5-year prospective surveillance study of antibiotic resistance among Salmonella entrica isolates and ceftriaxone therapy among children hospitalized for acute diarrhea. Clinical Therapeutics 2002;24:1585-1594.

Colla FL, Rodrigues LB, Dickel EL, Borsoi A, Nascimento VP, Santos LR. Avaliação in vitro de clorexidina, amônia quaternária e ácido peracético frente a amostras de Salmonella Heidelberg isoladas de abatedouro avícola em 2005 e 2009. Pesquisa Veterinária Brasileira 2012;32:289292.

Colla FL, Mion L, Parizotto L, Santos LA, Pilotto F, Rodrigues LB, et al. Perfil de sensibilidade aos antimicrobianos e eficácia de sanitizantes frente aos isolados de Salmonella spp. oriundos de carcaças suínas no Rio Grande do Sul. Pesquisa Veterinária Brasileira 2014;34:320-324.

EFSA. Scientific opinion of the panel on biological hazards on a request from the European food safety authority on foodborne antimicrobial resistance as a biological hazard [cited 2014 Ago 20]. Esa Journal 765:1-87, 2005. Availabel from: www.efsa.europa.eu/efsajournal.

Lorençon L, Nunes RV, Pozza PC, Pozza MSS, Appelt MD, Silva WTM. Utilização de promotores de crescimento para frangos de corte em rações fareladas e peletizadas. Acta Scientiarum 2007:29:151-158.
Mion L, Colla FL, Cisco IC, Webber B, Diedrich LN, Pilotto F, et al. Perfil de resistência a antimicrobianos por Salmonella Heidelberg isoladas de abatedouro avícola em 2005 e 2009. Acta Scientiae Veterinariae 2014;42:1197.

Reis EMF, Rodrigues DP, Almeida ACF, Hofer E. Prevalence of R-type ACSSUT in strains of Salmonella serovar Typhimurium DT193 isolated from human infections in Brazil. Pan American Journal of Public Health 2011;29:387-392

Rodrigues LB, Santos LR, Rizzo NN, Tagliari VZ, Trenhago G, Oliveira AP, et al. Salmonella and Listeria from stainless steel, polyurethane and polyethylene surfaces in the cutting room of a poultry processing plant. Acta Scientiae Veterinariae 2013;41:1164.

USDA. Performance standards for antimicrobial susceptibility testing: twenty-second information supplement. Clinical and Laboratory Standards Institute M100-S22 2012;32(3):1-184.

USDA. National Antimicrobial Resistance Monitoring System (NARMS): Enteric bacteria, animal arms [Animal Arm Annual Report]. Athens: Department of Agriculture, Agricultural Research Service; 2012.

Wilson IG Antimicrobial resistance of Salmonella in raw retail chickens, imported chicken portions, and human clinical specimens. Journal of Food Protection 2004;67:1220-1225.

WHO - World Health Organization. Critically important antimicrobials for human medicine. Copenhagen: Report of the 3nd WHO expert meeting, 2011 [cited 2014 ago22]. Availablfre from: http://apps.who. int/iris/bitstream/10665/77376/1/9789241504485_eng.pdf

Zimermann FC, Pinheiro D, Cesco MAO, Guayba J, Borsoi A, Fortes BFB, et al. Resistência antimicrobiana em amostras de Salmonella Hadar isoladas de carcaças de frango [cited 2014 Jan 24]. Anais do 35 Congresso Brasileiro de Medicina Veterinária; 2008: Porto Alegre. Rio Grande do Sul. Brasil. Available from: <http://www.sovergs.com.br/ conbravet2008/anais/cd/resumos/R0750-1.pdf> 
